Nick Taylor

DOI: $h$ ttp://dx.doi. org/10.18820/2519593X/pie. v34i1.2

ISSN 0258-2236

eISSN 2519-593X

Perspectives in Education

2016 34(1): 10-26

(C) UVIUFS

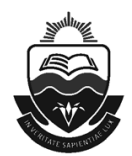

\section{Thinking, language and learning in initial teacher education}

\begin{abstract}
Initial teacher education (ITE) serves as a bridge between prospective teachers exiting the school system to enrol in teacher education faculties, on the one hand and newly qualified teachers (NQTS) who are embarking on a career in schooling on the other. The present paper describes the language and thinking skills student teachers bring to their ITE programmes and the conditions faced by NQTS when they enter schools on the other side of the chalk face. This is the context within which we ask the question: To what extent are the universities providing the teachers required by the school system? While a review of the literature, together with new evidence emerging from the Initial Teacher Education Research Project (ITERP) study, indicates that the answer to this question is by no means unequivocally positive, the Department of Higher Education and Training (DHET) has issued new regulations aimed at addressing the gap between current programmes and the demands of schooling. We conclude by arguing that the quality of ITE will only be improved once teacher educators move their practices closer to those of practitioners in the strong professions, which are characterised by the development of a strong theoretical knowledge base, from which effective protocols of practice may be derived and which is continuously interrogated by the practitioners themselves. We suggest that the place to start on this quest is the instruction of prospective primary school teachers in early literacy and numeracy.
\end{abstract}

Keywords: Pre-service teacher education, knowledge for teachers, inferencing skills, professional knowledge

\section{ITE: An integral part of the school system}

The South African school system currently serves to reproduce apartheid's grand plan five decades after the assassination of its principal architect (Taylor \& Muller, 2014). It is noteworthy that in the collective mind of public debate, the initial teacher education (ITE) sector is generally considered separate from schooling. In the quest for greater efficiency and improved quality in a school system that is manifestly underperforming, ITE hardly raises a mention outside the sector itself. Inappropriate political leadership, low parental involvement, poor governance and management, misguided curriculum reform, poor quality materials and ineffective in-service training all get their share of the blame in the ongoing debate about the state 
of South African schooling. Within the universities, there is great concern with the question of curriculum design - who should teach what to whom - and a feeling of frustration with the poorly prepared state of students entering ITE. However, these discussions hardly intersect with the frequent and furious public exchanges on how to improve the quality of learning outcomes. This paper is an attempt to begin a discussion on connecting ITE course design to the processes and outcomes of schooling.

Given a threshold of institutional leadership and management expertise - as currently exists in significant parts of the system - what goes on behind more than a quarter of a million closed classroom doors daily is fundamentally a function of teacher professional expertise. The demonstrably poor pedagogic facility exhibited by numerous teachers (see Hoadley, 2012 for example), coupled with the failure to advance teacher capacity through the multibillion rand in-service training (INSET) industry over more than three decades (Besharati \& Tsotsotso, 2015; NEEDU, in press), highlights the importance of ITE in rescuing schooling from its present predicament.

ITE serves as a bridge between prospective teachers exiting the school system to enrol in teacher education faculties, on one hand, and newly qualified teachers (NQTs) who are embarking on a career in schooling, on the other. The present paper describes the language and thinking skills student teachers bring to their ITE programmes and the conditions faced by NQTs when they enter schools on the other side of the chalk face. The assumption behind this approach is that it is through the analysis of these two sets of bracketing conditions that the following question can be adequately examined: To what extent are the universities providing the teachers required by the school system?

\section{ITE under the spotlight}

In the early 2000s, the ITE landscape in South Africa was radically restructured when teacher education became a national competence, with a move into the higher education sector. Shortly after the relocation, the Council for Higher Education conducted a review of qualifications in education, which was published in 2010. The findings of the review were discouraging. Across all four types of programmes reviewed - M.Ed., B.Ed., PGCE and ACE - fewer than half (48\%) received full accreditation with $22 \%$ either not accredited at all or 'on notice of withdrawal' and the remainder being conditionally accredited. According to the diagnosis of the Higher Education Quality Committee (HEQC), the greatest difficulties lay in programme design, raising for the reviewers the critical question as to:

... the extent to which academics responsible for these programmes understand the nature and purpose of each of them and how they are to respond to South Africa's specific needs in the area of teacher education (CHE, 2010: 147).

The review described a lack of consensus within the ITE field in South Africa around teaching practice: this was tightly regulated in some institutions and in others it was relatively unstructured. Few institutions could articulate the attributes they sought to develop in their students through work-based learning. The main concerns about the B.Ed. expressed by the review revolved around curriculum congestion and onerous regulatory requirements: "... the challenge of focusing simultaneously on a learning area, a phase and on pedagogy result in bloated programmes with insufficient depth or attention paid to subject or disciplinary depth" (CHE, 2010: 150-1). 
South Africa is not unique in expressing public concern about the appropriateness of ITE provision. Shortly after South Africa's HEQC review, the Australian federal government established a Teacher Education Ministerial Advisory Group to investigate the quality of ITE, the highly critical findings of which are contained in the Action Now report released in 2014 (Teacher Education Ministerial Advisory Group, 2014). The Teacher Prep Review (2014), an evaluation of ITE programmes in the US conducted by the National Council on Teacher Quality, was equally critical. The latter report was particularly scathing about the preparation of primary school teachers in teaching literacy:

We are disheartened that the teacher education field continues to disregard scientifically based methods of reading ${ }^{1}$ instruction: coursework in just 17 percent of programs equips their elementary and special education teachers to use all five fundamental components of reading instruction, helping to explain why such a large proportion of American school children (30 percent) never learn to read beyond a basic level (National Council on Teacher Quality, 2014: 3).

The HEQC review attributes what it calls the 'disarray' of initial teacher education in the US and SA to a lack of agreement about the curriculum and,

While 'disarray' is possibly too emotive a word to describe the state of the field in South Africa, a conclusion that is hard to avoid is that the field is riddled with difficulties.

\section{Professional knowledge}

Before we address the evidence bearing on our main research question, we turn to theoretical considerations concerning the nature of professional expertise, the pivotal role of teachers inducting learners into a systematised body of knowledge and the critical roles that language and cognition play in this process. Current debates concerning the knowledge and skills required for teaching were largely shaped by Shulman's legendary presidential address to the American Educational Research Association in 1985, where he discussed three knowledge content categories (subject matter, pedagogic and curricular) (Shulman, 1986). A more recent statement, which essentially covers the same ground, is given by Darling-Hammond and her colleagues, who summarise 'the real variables' pertaining to teacher effectiveness as follows:

... knowledge of the subject matter content to be taught and knowledge of how to teach that content to a wide range of learners, as well as the ability to manage a classroom, design and implement instruction, and work skilfully with students, parents, and other professionals (Darling-Hammond et al., 2005: 20).

The present paper does not encroach on this teacher-specific terrain but is rather concerned with the fundamental cognitive architecture and linguistic abilities that underlie, or enable the capacity to develop subject knowledge and the ability to use that knowledge in addressing real-world concerns. The reasoning developed in subject knowledge and

1 What the NCTQ means by 'scientific methods' of reading instruction are those advocated by the National Reading Panel (NRP) which, following a survey of 'high quality' research into the topic between 1997 and 2000, concluded that the teaching of reading is best affected through a combination of five techniques: phonemic awareness (hearing sounds in words), phonics (understanding sound/ letter relationships), fluency (oral and written reading proficiency), vocabulary (building a rich store of words and meanings) and comprehension (understanding the meaning of oral and written language) (National Reading Panel, 2000) 
its practical application forms a basis for the kinds of judgement practiced by adepts in all professional fields.

The nature of professional knowledge has long been the subject of debate and a number of reviews over many years. The classic work of Abbott (1988) presents an example of outstanding scholarship. A recent contribution is a collection of essays edited by Michael Young and Johan Muller: Knowledge, Expertise and the Professions (Young \& Muller, 2014a). In his chapter entitled Know-how, Knowledge and Professional Education, Christopher Winch (2014) embarks on an extensive discussion of the topic, commencing with the notion of epistemic ascent, which assumes that knowledge can be categorised into different types and that the relations between these categories can be described with a view of supporting the progression of learners. This brings us to the idea of curricular progression or growing the subject under study.

The term subject here refers to a body of knowledge organised around a defined field, which adopts characteristic methods for validating existing knowledge and acquiring new propositions. With specific respect to professional knowledge, Winch (2014) poses three criteria for establishing the extent to which a learner knows the subject. First, s/he will have an understanding of some coherent set of propositions making up the defined knowledge field in question. However, being able to recite a list of propositions does not constitute any sense of 'knowing' the discipline. Elaborating on Ryle's (1949) classic distinction between 'knowing that' (propositional knowledge) and 'knowing how' (how to deploy propositional knowledge), Winch describes two kinds of 'know how'. This brings us to the second criterion for assessing how well a learner knows the subject: s/he will understand at least some of the connections between propositions. In this regard, good subject knowledge is reflected in the learner's ability to find his/her way around the subject; to negotiate what David Guile (2014) calls the space of reasons: giving and asking for reasons and being able to justify what one says.

Winch's third test of subject expertise and second kind of 'know-how' is indicated by an understanding of how knowledge in the subject is tested, validated and added to. While only relatively advanced students of a subject may be expected to create new knowledge, understanding the test for validation of an inference or deduction within the discipline is a key expectation of knowing a subject.

From this perspective, an occupation can be said to be a profession when competent practice depends, in the first instance, on knowing one's way around a systematic body of knowledge. However, the professional also needs to know how to reason within the subject's propositional net and how to apply the knowledge to practical action. There are different levels at which learners can use subject knowledge for action: from the most basic technique, through to more complex applications of subject knowledge for practical action such as occupational capacity and project management. Winch emphasises the close relationship between propositional knowledge and professional action:

Professional expertise depends crucially on the ability to use systematic knowledge to inform practical judgement and action (Winch 2014: 52).

In the same vein, David Guile describes the exercise of professional expertise as "... making conceptually-structured professional (i.e. practical) judgements in context-specific circumstances" (2014: 81). Young and Muller (2014b) add that, in the development and deployment of a body of professional knowledge, two kinds of knowledge specialisation 
are distinguishable: knowledge specialised to conceptual generality (elaboration of theory) and knowledge specialised to purpose (practical application). The former is directed toward extending the generality and reach of the conceptual edifice while the latter is aimed at deriving a more elegant or efficient solution to a technical problem. Separated here for analytical purposes, these two strands of knowledge development generally work best in tandem. Thus, Galileo's achievements in astronomy in the seventeenth century were enabled by advances in the lens-grinding industry (knowledge specialised to practical purpose), which in turn was based on the physics of optics and the laws governing the behaviour of light under conditions of reflection and refraction (knowledge specialised to generality).

The final point concerning Winch's conceptual map of professional expertise, and a crucial one for what follows in the remainder of the present paper, is to emphasise his conclusion that reaching a level of professional knowledge on the part of a learner involves the exercise of relatively complex forms of reasoning. These complex forms of reasoning include inductive inference (formal or material), hypothetico-deduction and where the knowledge base is founded on experimental methods or statistical techniques (such as physics or psychometrics), an understanding of measures of significance and confidence.

Drawing on this perspective, we may say that the ability to exercise complex forms of reasoning is necessary for the acquisition, application and elaboration of professional expertise. With specific respect to prospective teachers, this does not imply that students should come to their ITE studies with these capacities fully formed but some threshold level may be required before significant progress can be made. The questions then arise as to how these reasoning abilities - the building blocks of professional judgement - are nurtured among children and young adults in schools and what kinds of reasoning skills they bring to their ITE courses.

\section{Language and cognition}

The assumptions underlying the argument that follows lie in the intersection of language and cognition. Debates in this field are concerned with the degree of intersection and the precise nature of linkages between words and thought but no one seriously disputes their close connection. In the most recent review of this field, Deák (2014) places Chomsky at one end of the spectrum with his notion that language development is independent of cognition. By contrast, constructivist and biologically based perspectives recognise that language processing is cognition, language use is distributed cognition and understanding children's capacity for language means understanding the development and recruitment of general learning and cognitive processes (Deák, 2014: 290). Following this line of thinking, Perlovsky (2009) claims empirical evidence for the joint evolution of human language and cognition. According to him, mental models of concepts such as 'shoe', may be grounded in direct sensory experience only at the very bottom of the mind hierarchy: at higher layers,

... cognitive concepts are grounded in language concepts ... and language models ... are grounded in talking with other people and mutual understanding ... (Perlovsky, 2009: 253)

In other words, higher order or concepts that are more abstract may be explained in terms of lower level, simpler concepts using spoken and written language. Learning language hierarchy at all layers is grounded in communication with other people around; people talk to and understand each other. Try to teach a dog to understand the word 'rational', or any 
abstract concept, whose meaning is based on several hierarchical layers; this is not possible (Ibid: 253).

These views provide a theoretical perspective on the intuitively obvious proposition that high levels of cognitive processing are dependent on high levels of literacy - speaking, reading and writing - in the language of learning. It follows that in order to engage their learners productively in the development of conceptual understanding teachers should be highly literate in this language. It also seems obvious that literacy and cognitive development are complicated when the language of learning does not coincide with the language the learner speaks most frequently at home, a vast topic in its own right that cannot be entertained in the present paper. It is in this vein that Balfour (2012) calls for a revival of research on language pedagogy for second language acquisition and further research into better understanding of home-language syntax in relation to target-language syntax, in order to create the scaffolding to enable learners to make the transitions necessary for effective learning.

The concern in this paper is that prospective teachers are entering into pre-service teacher education programmes from a system that indicators suggest are not adequately preparing the vast majority of learners to develop the levels of literacy or complex reasoning skills that enable inductive reasoning and hypothetico-deduction.

\section{The roots of reasoning: Literacy comprehension in schools}

\section{Primary schools}

Around the world primary school curricula, including the South African Curriculum and Assessment Policy Statements (CAPS), specify that children should learn to read and write fluently and at relatively complex levels of cognitive skill by the end of the third grade. Then, moving into the fourth grade, learners are assumed to progress, from learning to read to reading to learn, using their literacy skills to investigate a range of disciplinary fields, at increasing levels of complexity. It is clear from the results of numerous international and national tests that the South African system, as a whole, falls far short of these ideals.

The roots of the reasoning abilities described by Winch and others in our theory of professional expertise are explicitly mentioned in the taxonomy of reading comprehension skills on which the Progress in Reading Literacy Study (PIRLS) ${ }^{2}$ is based. The PIRLS scheme defines reading skills exhibited at four benchmark levels: advanced, high, intermediate and low (table 1).

2 The 2006 administration of PIRLS was the third iteration internationally of the study and the first in which South Africa participated, along with 39 other countries. Grade 4 and 5 learners write the tests. In South Africa, learners wrote the test in one of the 11 official languages, selected by the school as representing the home language of the majority of learners. 
Table 1: PIRLS Benchmark descriptors and grade 4 scores

\begin{tabular}{|l|c|l|c|c|}
\hline \multicolumn{1}{|c|}{$\begin{array}{c}\text { PIRLS } \\
\text { Benchmark }\end{array}$} & Score & \multicolumn{1}{|c|}{ Reading Skills } & $\begin{array}{c}\text { Int. } \\
\text { median }\end{array}$ & $\begin{array}{c}\text { SA } \\
\text { mean }\end{array}$ \\
\hline Advanced & $625+$ & $\begin{array}{l}\text { Advanced readers: Learners are able } \\
\text { to integrate information across relatively } \\
\text { challenging texts and can provide full text- } \\
\text { based support in their answers. Learners } \\
\text { are able to make interpretations and can } \\
\text { demonstrate that they understand the } \\
\text { function of organisational features in texts. }\end{array}$ & $7 \%$ & $1 \%$ \\
\hline High & $550-625$ & $\begin{array}{l}\text { Competent readers: Learners exhibit } \\
\text { the ability to retrieve significant details } \\
\text { embedded across the text, to provide } \\
\text { text-based support for inferences, and to } \\
\text { recognise main ideas, some textual features } \\
\text { and elements and are able to begin to } \\
\text { integrate ideas and information across texts. }\end{array}$ & $41 \%$ & $3 \%$ \\
\hline Intermediate & $475-549$ & $\begin{array}{l}\text { Some reading proficiency: With regard } \\
\text { to reading stories, learners are able to } \\
\text { understand the plot at a literal level and to } \\
\text { make some inferences and connections } \\
\text { across texts. }\end{array}$ & $76 \%$ & $7 \%$ \\
\hline Low & $400-474$ & $\begin{array}{l}\text { Basic reading skills: Learners are able to } \\
\text { recognise, locate and reproduce information } \\
\text { that is explicitly stated in texts, and make } \\
\text { straightforward inferences. }\end{array}$ & $94 \%$ & $13 \%$ \\
\hline
\end{tabular}

Source: Constructed from Howie et al., 2008, emphasis added

The bottom row of table 1 shows that while the international median achievement for the low benchmark across 40 participating countries is $94 \%$ only $13 \%$ of South African grade 4 learners demonstrate this level of reading comprehension. Thus, $87 \%$ of SA grade 4 learners struggle to reproduce information explicitly stated in the text and are able to make straightforward inferences, as opposed to a median of only $6 \%$ internationally.

\section{High schools}

At high school level, we can continue to trace the development of the reasoning abilities that form such an integral part of Winch's theory of professional knowledge, through an examination of the assessed curriculum for English First Additional Language (EFAL), the language of learning and teaching (LoLT) for $80 \%$ of South African learners. The report of the Ministerial Task Team on NSC (DBE, 2014) makes its strongest recommendations with respect to the level of reasoning skills demanded by EFAL. The task team characterises many students in the school system as 'semi-lingual' both in the LoLT and their home language, exhibiting small vocabularies and incorrect grammar, consciously thinking about their language production, being stilted and uncreative with each language and finding it difficult to think and express emotions in either language. These features influence learners' understanding of all their school subjects. The introduction of English into the foundation phase CAPS curriculum is an attempt to improve standards of LoLT for the majority of children but as the task team report notes, the success of this policy will depend on the language proficiency and pedagogical skills of teachers.

According to the task team, reviews of the quality of the 2010 EFAL NSC papers by three international benchmarking authorities - Cambridge International Examinations (CIE), the 
Scottish Qualifications Authority (SQA) and the Board of Studies, New South Wales (NSW) collectively found:

- The cognitive levels assessed in the exam questions are heavily weighted towards lower-order skills such as literal comprehension and grammar translation tasks with far fewer questions testing the higher-order cognitive processes of inference, evaluation and appreciation.

- Students are not given sufficient opportunity to explain and analyse the content, purpose and audience of the texts and this reflects an insufficient focus on critical literacy and language analysis skills.

- The majority of questions require short-answers and students can avoid writing an essay entirely in the literature paper (paper 2).

- The grammatical activities themselves reflect a drill and practise approach to language learning, which does not support the need to develop students' language for work and participation in the broader community.

The Ministerial task team concludes, "The level of most learners and teachers' proficiency in English is too low to use English as LoLT optimally, and so to realise their potential" (DBE, 2014: 76). The report makes a number of recommendations to address this situation, including intensive training of teachers in EFAL through INSET and ITE. Furthermore, the task team proposes raising the pass requirements for Bachelor $(50 \%)$ and Diploma $(40 \%)$ study. Wedekind (2013) has calculated that the implementation of the latter recommendations would hardly change the numbers qualifying for Bachelor study but would significantly decrease those reaching entrance to Diploma-level courses. Perhaps the most important recommendations are concerned with raising the cognitive demands of NSC exam items in EFAL: longer texts should be set as comprehension exercises while the kinds and level of comprehension tasks should significantly reduce recall and retrieval type items and include more questions demanding application and inferential reasoning.

\section{Demands on NQTs when they enter schools}

The previous section outlines the reasoning skills that students bring to their ITE studies. However, what about the other side of the sandwich, the challenges they will face when entering schools as newly qualified teachers (NQTs)? At least four important conditions are relevant to the present discussion.

1. English is the LoLT in $90 \%$ of schools and for $80 \%$ of learners, including those from the poorest families living in rural villages, urban townships and squatter camps this is EFAL. This means that the most disadvantaged learners are required to engage cognitively with all disciplinary areas in a language that is not their mother tongue and which the Ministerial task team has declared to be inadequate for the task. These conclusions, when read in the light of the above discussion on language and cognition, would go a long way to explaining the continued educational disadvantage of the majority of South Africans, including their low and slow success rates through higher education. Although much has been achieved in expanding the middle class over the last two decades, the education system - schools, universities and colleges - is hampering progress in this direction, reproducing the disadvantage of the poorest citizens and language policy and practice are inextricably implicated in this vicious circle. 


\section{Poor subject competence among teachers}

The SACMEQ tests administered to grade 6 teachers of maths and English in a national sample of primary schools indicate low levels of the sorts of reasoning skills identified in Winch's notion of subject expertise. The SACMEQ tests are pitched at grades 6-8 levels, covering a relatively wide spectrum of cognitive demands (table 2).

Table 2: SACMEQ teacher tests - results in English for grade 6 teachers, by cognitive skill

\begin{tabular}{|c|c|c|c|}
\hline Retrieve & Infer & Interpret & Evaluate \\
\hline 75.06 & 55.21 & 36.61 & 39.73 \\
\hline
\end{tabular}

Source Taylor and Taylor, 2013

While South African teachers did relatively well on questions requiring the simple retrieval of information explicitly stated in a passage of text (75.1\%), scores dropped dramatically as soon as the higher cognitive functions of inference $(55.2 \%)$, interpretation $(36.6 \%)$ and evaluation (39.7\%) were invoked. These results are not surprising given that the large majority of teachers were schooled in EFAL and received their teacher training in largely dysfunctional colleges during the apartheid era.

\section{Inadequate reading pedagogies are practiced in the majority of primary schools}

A third factor to be addressed by new teachers entering schools, which is of great relevance to ITE, concerns the pedagogical milieu that dominates schools serving the poor. Inappropriate pedagogy results in the large majority of learners reaching grade 5 essentially illiterate, as shown in table 1 with regard to the PIRLS scores. The pedagogies predominantly seen in observing two grade 2 reading lessons in 133 rural primary schools in 2013, consisted of much chanting in chorus when facing a Big Book and very little independent reading by individuals. Few children are asked to decode and/or explain the meaning of words, phrases and sentences. Writing over the year reaches levels no more than $25 \%$ of curriculum specifications (NEEDU, 2013; 2014a). This inefficient pedagogy lies behind the country's poor performance on comparative tests. Supporting the PIRLS findings reflected in table 1, an analysis of an assessment undertaken by NEEDU, tells us that the large majority of African grade 5 children located in rural schools decode simple words at such a slow rate that they cannot understand what it is that they are reading (Draper \& Spaull, 2015). The implications are that newly qualified teachers in the intermediate and even the senior phase will be required to identify and remediate reading difficulties experienced by up to half the class in many schools. Are they being adequately prepared for this?

\section{Schools tend not to recruit and deploy primary school teachers according to subject specialisation}

The assumption among most principals is that a qualified primary school teacher can teach any subject. As a result, most teachers at primary level will be required to teach most subjects, including maths and English, at some or other stage during their careers. This feature poses serious questions for the ITE sector: can we realistically expect schools to be more efficiently managed in the near future or should we be preparing primary school teachers to be knowledgeable about subject content and pedagogy in the most important disciplines? 


\section{How is ITE addressing these conditions?}

How is the sector bridging the gap between the abilities that student teachers bring to ITE and the demands of the schools their NQTs will enter on graduation? Moreover, in the first instance, how is ITE developing the language and thinking abilities required, first for the development of subject expertise and second, for the exercise of professional judgement? We illustrate the point with analysis of recent SAQMEC findings and examples from the specifications concerning the curricula for primary school teachers specialising in the B.Ed. (intermediate phase teaching) offered in 2012.

One item of good news in this regard is that, when the SACMEQ teacher test results that measure teacher subject knowledge are disaggregated by age, teachers in the category 19 to 29 outperform their older colleagues by some margin; furthermore, teachers in this age cohort are better able to increase the mean performance of students (figure 1) (Armstrong, 2015).

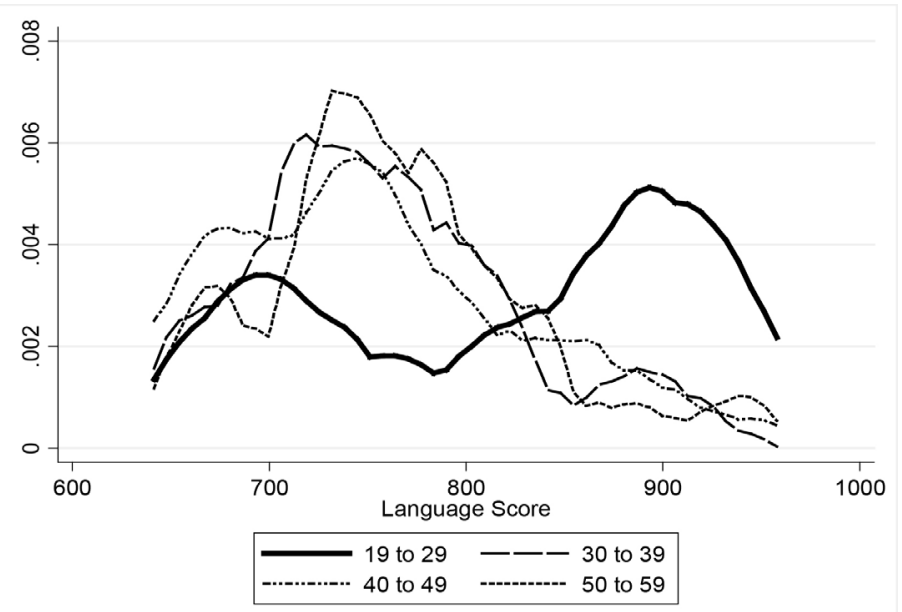

Figure 1: SACMEQ III Teacher language test scores by age

Source: Armstrong, 2015

These findings are significant and could be explained in one of two ways. Younger teachers may relate better to their students because they are closer in age to them than their older counterparts. Another possibility is that changes to pre-service teacher education may have left teachers who qualified under the new university-based system better equipped to teach. Armstrong (2015) supports the second option, which implies that since the reorganisation of the initial teacher education terrain around 2002, newly qualified teachers have received an education better suited to teaching than their older peers who completed their qualifications in the training colleges.

Armstrong's findings are a welcome item of news for a sector that is still in the process of addressing the very serious indictment delivered by the HEQC in its review of ITE programmes, published in 2010 (CHE, 2010). 
One component of the Initial Teacher Education Research Project (ITERP) consisted of examining the B.Ed. (intermediate phase teaching) at five universities offering ITE; institutions were selected to ensure a spread across the main institutional types, distinguished by history under apartheid, academic or technical and geographic location. Collectively they produced close to half of all South African teachers in 2014. In her analysis of the English curricula offered to students specialising in the intermediate phase, Reed (2014; see also Reed and Bowie, this volume) notes that, in recognition of the poor language and reasoning skills that students bring to the university, all but one of the ITERP sample institutions offers academic literacy to student teachers. To what extent do these programmes address the difficulties most learners face in the reading, writing and reasoning skills demanded by professional knowledge development, given the low levels of English proficiency they bring from school? A great deal has been written on this subject and on the question of academic development in general but it seems that this question is far from resolved (see, for example, CHE, 2013; Lewin and Mawoyo, 2014).

Table 3 provides a comparison of the English curricula offered to B.Ed. students specialising in the intermediate phase but not specialising as teachers of English, across the 5 (A to $E$ ) institutions (see paper by Bowie and Reed in this issue for further detail).

Table 3: Proportion of B.Ed. degree made up by English course credits for IP teachers

\begin{tabular}{|c|c|c|c|c|l|}
\hline Elective & A & B & C & D & \multicolumn{1}{|c|}{ E } \\
\hline IP English Specialists & $120(25 \%)$ & $162(34 \%)$ & $72(15 \%)$ & $120(25 \%)$ & $\begin{array}{l}\text { HL: } 72(15 \%) \\
\text { AL: } 5(1 \%)\end{array}$ \\
\hline IP English Generalists & $30(6 \%)$ & $28(6 \%)$ & $36(7.5 \%)$ & $24(5 \%)$ & $\begin{array}{l}\text { HL: } 28(6 \%) \\
\text { FAL: } 29(6 \%) \\
\text { AL: } 5(1 \%)\end{array}$ \\
\hline
\end{tabular}

Source: Reed, 2014

The most striking feature of the table is the paucity of English offered to those student teachers who had not selected to specialise as English teachers. Based on the theoretical arguments about the nature of professional knowledge outlined above and given the poor levels of English proficiency demanded by the school curriculum, it would seem obvious that most students would benefit greatly from intensive courses in English language and literature. These courses should explicitly seek to develop the sophisticated reasoning skills required for the acquisition and exercise of professional expertise. Indeed, our theory predicts that intensive courses in English for all primary school teachers, focusing explicitly on higher order reasoning in verbal and written communication, is likely to have a profoundly positive influence on the development of professional expertise among student teachers.

In terms of the content of English courses offered to students specialising in English teaching in the IP, Reed found low levels of attention paid to teaching English as FAL and to understanding and applying appropriate pedagogies for teaching reading and writing (Reed, 2014). Teaching literacy is complex and challenging. What is evident from the data is that each of the universities in the study approaches this 'topic' differently but may not be doing enough to equip beginner teachers with the knowledge and skills to support struggling 
readers on the one hand or to extend excellent readers on the other. The omission of any input on literature for children and adolescents at some institutions and the limited attention given to this important area in some others is also a cause for concern.

Since the HEQC evaluation, the sector has seen a National Teacher Education Summit, the publication of the Integrated Strategic Planning Framework for Teacher Education and Development in South Africa (ISPFTESA) (DBE/DHET, 2011), and the promulgation of two iterations of the Minimum Requirements for Teacher Education Qualifications (MRTEQ) (DHET, 2011; 2015). As is the case with the evolution of the school curriculum since 1994, these developments collectively exhibit a drive towards more precise content specification. Thus, while the Norms and Standards for Educators (DoE, 2000a; 2000b) specified only that programmes meet some or other combination of the broadly defined seven educator roles ${ }^{3}$, MRTEQ, while relegating the seven roles to an appendix, begins to explicate the knowledge and skills needed to meet the classroom demands faced by new teachers, as described in the previous section.

In terms of the different demands of MRTEQ, all IP student teachers must specialise in the teaching of two languages (comprising Home Language teaching in one of the official languages and First Additional English Language teaching). They must also specialise in at least two other subjects, in addition to having a sufficient broad background knowledge to understand the requirements of all subjects in the intermediate phase curriculum (DHET, 2015: 24). Furthermore, those who do not select mathematics as one of their teaching specialisations must nevertheless develop a good understanding of the fundamental mathematical concepts that underpin the intermediate phase mathematics curriculum up to at least NQF Level 5 (ibid: 25).

These specifications, if carried through to curricula and effective programmes should more adequately equip IP teachers to address three of the four contextual factors faced by NQTs entering primary schools, as described in the previous section. The odd one out is the teaching of reading and writing. MRTEQ makes no explicit mention of literacy instruction for prospective intermediate phase (IP) teachers, a curious omission, given that the PIRLS results (table 1) and all subsequent comparative tests clearly indicate that the large majority of South African grade 4 and 5 children are unable to read and comprehend age-appropriate texts at the most elementary level.

\section{Conclusion}

Returning to our main research question: To what extent are the universities providing the teachers required by the school system? The ITERP findings quoted above indicate glaring gaps in the curricula of at least a significant proportion of the sector (Taylor, 2014a). This is the situation castigated by the $\mathrm{CHE}$ report in 2010 and which government is attempting to address through the MRTEQ regulations. All universities have recently completed or are in the process of doing a 'recurriculation' exercise in response to MRTEQ.

The foregoing discussion indicates that initial teacher education (ITE) has a long way to travel in order to close the gap between pre-MRTEQ curricula, on the one hand and the

3 Specialist in a phase, subject or practice; learning mediator; interpreter and designer of learning programmes and materials, leader, administrator and manager, scholar, researcher and lifelong learner, assessor and a community, citizenship and pastoral role. 
demands of the school system and government regulations, on the other. The argument presented in the present paper is that the first step toward putting the occupation of educating onto a firmer professional footing would be to pay attention to the professional knowledge base. How would this be translated into practice, for example, with respect to literacy instruction in the primary school? The question must be answered epistemologically (through the content of the curriculum) and strategically (in terms of procedure).

\section{The professional curriculum}

As we have argued, professional expertise consists of a combination of conceptual understanding and fit-for-purpose action. In this milieu, reasoning ability is the medium of knowledge exchange, and English is the vehicle. However, what about the content? Taking the example of literacy instruction, the following questions must be asked of the current state of professional knowledge:

- Do we have a coherent theory of literacy instruction, or is the field still characterised by name-calling across ideological barriers, with no way of adjudicating the claims of competing assertions?

- Do we have shared knowledge of well-defined reading pedagogies derived from and feeding into the theory that are effective in suburban, township and rural schools in South Africa?

- Are newly qualified teachers able to operationalise this into professional knowledge to teach reading effectively?

\section{Becoming professional}

According to our theory, teaching cannot be classified as a profession, in the first instance because practice is not reliably guided by a formal knowledge base. There are those who think that this is a good thing, that teaching is more of an art than a science, based largely on tacitly acquired routines (Taylor, 2014b). According to this view, attempts to formalise the knowledge base would undermine teachers and inhibit the autonomy required to respond to a myriad of contingent situations, which arise daily in classrooms. Others envisage the emergence of a theory of literacy instruction, for example, and associated pedagogical routines, the combination of which, in the hands of competent teachers, are effective in teaching reading in South African classrooms. Would this not be the most important step the ITE sector could take to improve the state of school and post-school learning dramatically?

There are two views about how an occupational grouping like teaching could become more professional. There are those who adopt what might be called an exogenous approach, which assumes professional status is conferred from outside; that if the occupational field of teaching were treated with more respect and not subjected to so much monitoring and testing, they would have more space to exercise their full creative potential and behave more professionally. I would argue that causality in this case works the other way around, that once the occupational field can demonstrate that its theories point to practices, which are effective, which reliably do the job then it will generate the kind of respect accorded members of high status professions. This is the endogenous approach: social trust in an occupation derives from the ability of the field to demonstrate that its theories and practices are more effective in providing a particular service than those of competing groups. The first marker of a 
professional field of labour is that it is able to demonstrate that its practices are relatively more effective than those of the competition.

Now, it is one thing to achieve this first marker with respect to one or more parts of the field and certainly, we have a wide range of practices in ITE, as table 3 amply shows. However, it is quite another to achieve it as part of a collective endeavour, across the entire sector. This is the second mark of a profession: there is consensus on best practices. The requirement is not uniformity - otherwise, there would be no possibility of innovation, even revolt and progress - but at least there should be broad convergence on a limited number of minimum sets of practice protocols and understanding them theoretically.

The third characteristic of a profession is that its knowledge and practice standards are maintained and jealously guarded by practitioners within the occupational field, not by government. This is professional quality assurance, as opposed to bureaucratic managerialism. It could not be any different, since only adepts within a field have the expertise to judge the value of new professional knowledge claims and to certify novice entrants into the profession. This is one of the most important features of the strong professions and again it is practised in the breach in the teaching sector. In addition, under these conditions, as Darling-Hammond and Hyler (2013: 1) have warned:

The extent to which an occupation is micromanaged by rules from without is directly related to the extent to which it fails to maintain high, common standards of competence and professional practice

Finally, in the face of the enormous task of professionalising the field of teaching and teacher education, which will be decades in the making, how can we make a start that has a good chance of success within a reasonable time horizon? I want to suggest that we take the case of literacy and numeracy and commit ourselves, as a field, to developing effective literacy and numeracy programmes for pre-service teacher education within 10 years. This would require the participation of government, statutory bodies and the unions but I hope I have made a convincing case that the initiative should be led by the ITE field. Strengthening the professional knowledge base of teaching, looking both inwardly to the development of disciplinary theory and outwardly to the field of practice, is a prerequisite for developing the kinds of content and pedagogic knowledge and skills required by new teachers.

\section{References}

Abbott, A. 1988. The system of professions: An essay on the division of expert labor. Chicago: University of Chicago Press.

Armstrong, P. 2015. Teachers in the South African education system: An economic perspective. Unpublished PhD thesis. Stellenbosch: University of Stellenbosch.

Balfour, R. 2012.. The return to reading: Acquisition, reading, research on narrative and the implications for a multilingual pedagogy for higher education in South Africa. Alternation, 19(2), 190-210.

Besharati, N. \& Tsotsotso, K. 2015. In search for the education panacea: A systematic review and comparative meta-analysis of interventions to improve learner achievement in South Africa. Unpublished research report. Johannesburg: University of the Witwatersrand. 
Council on Higher Education (CHE). 2010. Report on the national review of academic and professional programmes in education. Pretoria: Council on Higher Education.

Council on Higher Education (CHE). 2013. A proposal for undergraduate curriculum reform in South Africa: The case for a flexible curriculum structure. Report of the task team on undergraduate curriculum structure. Pretoria: Council on Higher Education.

Darling-Hammond, L., Holtzman, D.J., Gatlin, S.J. \& Heilig, J.V. 2005. Does teacher preparation matter? Evidence about teacher certification, Teach for America, and teacher effectiveness. Education Policy Analysis Archives, 13(42), 1-51. http://dx.doi.org/10.14507/ epaa.v13n42.2005

Darling-Hammond, L. \& Hyler, M. 2013. The role of performance assessment in developing teaching as a profession. Available at http://www.rethinkingschools.org/ archive/27_04/27_04_darling-hammond_hyler.shtml [Accessed 11 November 2015].

Deák, G.O. 2014. Interrelations of language and cognitive development. In P. Brooks \& V. Kampe, (Eds.). Encyclopaedia of language development. Los Angeles: SAGE. pp. 284-291.

Department of Basic Education (DBE). 2014. Ministerial task team report on the national senior certificate (NSC). Pretoria: Department of Basic Education.

Department of Higher Education and Training (DHET). 2011. The minimum requirements for teacher education qualifications. Department of Higher Education and Training. Government Gazette, 34467.

Department of Higher Education and Training (DHET). 2015. Revised policy on the minimum requirements for teacher education qualifications. Department of Higher Education and Training. Government Gazette, 38487.

Department of Basic Education/Deparment of Higher Education and Training (DBE/DHET). 2011. Integrated strategic planning framework for teacher education and development in South Africa. Pretoria: Department of Basic Education and Department of Higher Education and Training.

Draper, K. \& Spaull, N. 2015. Examining oral reading fluency among grade 5 rural English Second Language (ESL) learners in South Africa: An analysis of NEEDU 2013. South African Journal of Childhood Education, 2(5), 44-77.

Department of Education (DoE) 2000a. Norms and standards for educators. Pretoria: Department of Education.

Department of Education (DoE) 2000b. Criteria for the recognition and evaluation of qualifications for employment in education, based on the norms and standards for educators. Pretoria: Department of Education.

Guile, D. 2014. Professional knowledge and professional practice as continuous recontextualisation. In M. Young \& J. Muller (Eds.). Knowledge, expertise and the professions. London: Routledge. pp. 78-92.

Hoadley, U. 2012. What do we know about teaching and learning in South African schools? Education as Change, 16(2), 187-202. http://dx.doi.org/10.1080/16823206.2012.745725

Howie, S., Venter, E., van Staden, S., Zimmerman, L., Long, C., du Toit, C., Sherman, V., Archer, E. 2008. PIRLS 2006 summary report: South African children's reading achievement. Pretoria: Centre for Evaluation and Assessment, University of Pretoria. 
Lewin, T. \& Mawoyo, M. 2014. Student access and success: Issues and interventions in South African universities. Cape Town: Inyathelo, The South African Institute for Advancement.

National Council on Teacher Quality (NCTQ). 2014. 2014 Teacher prep review: A review of the nation's teacher preparation programs. Washington DC: National Council on Teacher Quality.

National Reading Panel. 2000. Teaching children to read: An evidence-based assessment of the scientific research literature on reading and its implications for reading instruction. Report of the subgroups. Washington DC: US Department of Health and Human Services.

National Education Evaluation and Development Unit (NEEDU). 2013. NEEDU national report 2012: The state of literacy teaching and learning in the foundation phase. Pretoria: National Education Evaluation and Development Unit.

National Education Evaluation and Development Unit (NEEDU). 2014a. NEEDU reading study 2013: The state of reading in grade 5 in selected rural primary schools. Pretoria: National Education Evaluation and Development Unit.

National Education Evaluation and Development Unit (NEEDU). 2014b. NEEDU national report 2013: Teaching and learning in rural primary schools. Pretoria: National Education Evaluation and Development Unit.

National Education Evaluation and Development Unit (NEEDU). (in press). NEEDU National report 2014: Prepared for the twenty-first century? The quality of high school education in South Africa.

Perlovsky, L. 2009. Language and cognition. Neural Networks, 22, 247-257. http://dx.doi. org/10.1016/j.neunet.2009.03.007

Reed, Y. 2014. Report on English courses for intermediate phase student teachers at five universities. Johannesburg: JET Education Services. Available at www.jet.org.za [Accessed 20 January 2016].

Ryle, G. 1949. The concept of mind. London: Hutchinson.

Shulman, L. 1986. Those who understand: knowledge growth in teaching. Educational Researcher, 15(2), 4-14. http://dx.doi.org/10.3102/0013189X015002004

Taylor, N. 2014a. An examination of aspects of the B.Ed. curricula for intermediate phase teachers at five higher education institutions: Summary report. Johannesburg: JET Educational Services.

Taylor, N. 2014b. Knowledge and teacher professionalism: the case of mathematics teaching. in M. Young \& J. Muller (Eds.). Knowledge, expertise and the professions. London: Routledge. pp. 171-184.

Taylor, N. \& Muller, J. 2014. Equity deferred: South African schooling two decades into democracy. In J.V. Clark (Ed.). Closing the achievement gap from an international perspective: transforming STEM for effective education. Dordrecht: Springer. pp. 1-13. http://dx.doi. org/10.1007/978-94-007-4357-1_13

Taylor, N. \& Taylor, S. 2013. Teacher knowledge and professional habitus. In N. Taylor, S. van der Berg \& T. Mabogoane. Creating effective schools: Report of South Africa's national schools effectiveness study. Cape Town: Pearson. pp. 204-233. 
Teacher Education Ministerial Advisory Group. 2014. Action now: Classroom ready teachers. Available at http://www.studentsfirst.gov.au/teacher-education-ministerial-advisory-group [Accessed 11 March 2015].

Wedekind, V. 2013. NSC pass requirements: A discussion document for Umalusi on the NSC pass mark. Pretoria: Umalusi.

Winch, C. 2014. Know-how, knowledge and professional education. In M. Young \& J. Muller (Eds.). Knowledge, expertise and the professions. London: Routledge. pp. 47-60.

Young, M. \& Muller, J. 2014a. (Eds.). Knowledge, expertise and the professions. London: Routledge.

Young, M. \& Muller, J. 2014b. From the sociology of professions to the sociology of professional knowledge. In Young and Muller (Eds.). Knowledge, expertise and the professions. London: Routledge. pp. 3-17. 